Hydrogen fuel in transportation

doi:10.2478/mape-2019-0016

Date of submission to the Editor: 04/2018

Date of acceptance by the Editor: 07/2018

MAPE 2019, volume 2, issue 1, pp. 161-171

Jiří Machač

Milan Majer

VSB-Technical University Ostrava, Czech Republic

\title{
INTRODUCTION
}

Lightest and most elementary chemical element in the periodical table is hydrogen. It is recognized under symbol $\mathrm{H}$. Hydrogen is light gas without color and scent highly reactive with oxygen and halogens. It is the most abundant element in the universe and it was discovered in 1776 by English scientist Henry Cavendish. Nowadays the consumption of hydrogen per year is almost 45 million of tons worldwide and it is highly expected that this number will only increase in the future. Most import use of hydrogen in future is its use as fuel in industry and transportation. There are two possibilities of use for hydrogen. Direct combustion in the combustion engines or use as fuel for hydrogen fuel cells producing electric energy.

\section{ELECTRICITY PRODUCTION}

Total production of electric energy in 2006 in OECD countries was 10373.4 TWh (Fig. 1). Following charts are comparing sources of electric energy production and showing what is total portion of renewable sources in total production of OECD countries (Organization for Economic Co-operation and Development) (Energetika v ČR, 2019)

Structure of electricity production in OECD (2010)

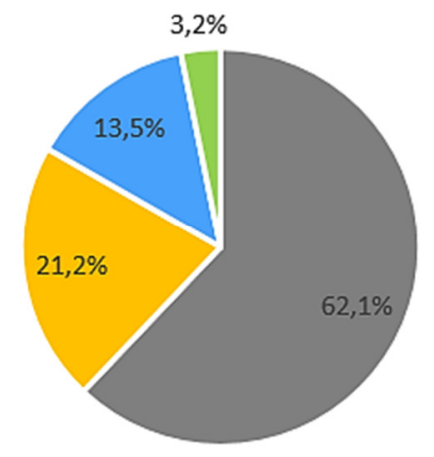

" Fossil fuel $\approx$ Nuclear $\approx$ Water $\approx$ Other
Structure of electricity production in OECD (2016)

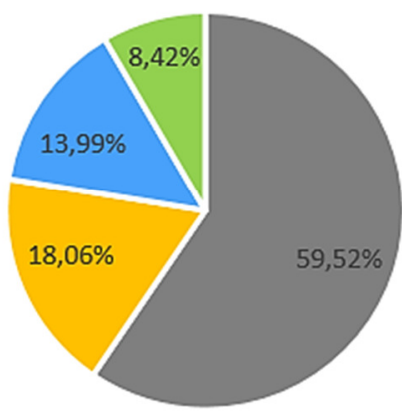

घ Fossil fuel $\approx$ Nuclear $\approx$ Water ॥ Other

Fig. 1 Structure of electricity production

* jiri.machac@vsb.cz 


\section{HYDROGEN PRODUCTION}

Production of hydrogen is possible in wide range of methods and various inputs. In worldwide production of hydrogen is dominating production from fossil fuels, that we should reduce and try to produce hydrogen more ecologically (Bołoz \& Midor, 2018). Daily production of hydrogen is almost $1.5 \mathrm{mld}$. $\mathrm{Nm}^{3}$. A Figure 2 is shown percentage representation of methods that are used for hydrogen production (Energetika $v$ ČR, 2019).

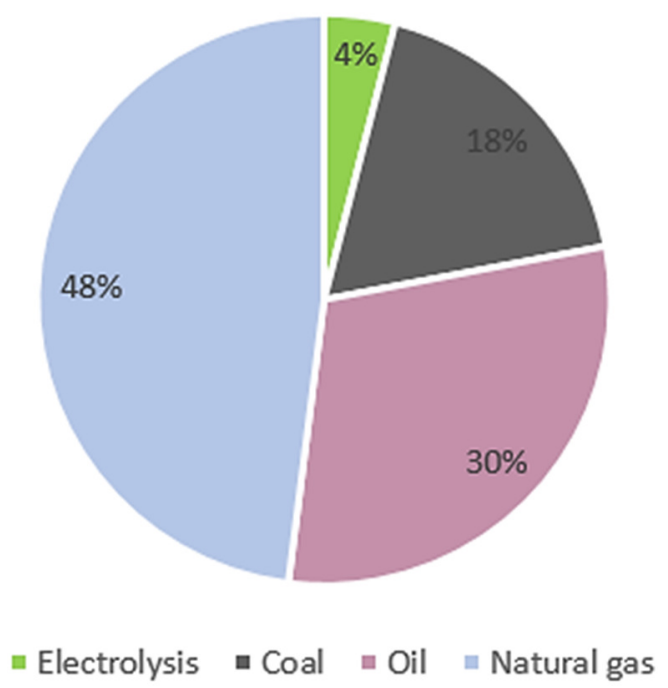

Fig. 2 Sources for hydrogen production

Production of one $\mathrm{m}^{3}$ of hydrogen by electrolysis consumes $4.8 \mathrm{kWh}$ of electric energy. In future hydrogen could be produced exclusively from renewable sources (wind, solar energy) (Mlčoch et al., 2015).

Almost $95 \%$ of production of hydrogen is immediately used in the industry. Total hydrogen production is $1 \%$ of worlds consumption of energy per day (Sankir et al., 2017).

\section{Hydrogen production methods}

- Natural gas reforming - nowadays the cheapest and most widespread method. Heat for reforming reaction and conversion of carbon dioxide is delivered directly from natural gas combustion

- Electrolysis of water - process of water fission to hydrogen and oxygen with help of electricity

- High temperature electrolysis - part of delivered energy is electric energy and part is delivered in form of heat, that is increasing efficiency of whole process

- Thermochemical cycles - water is divided to hydrogen and oxygen by the chain of chemical reactions, that are using energy in high temperature heat form (Matisková et al.,

- Biotechnological production of hydrogen - production of hydrogen by microorganisms

- Hydrogen fermentation - takes part without sunlight. Organic materials are used as primary source of hydrogen and also as source of energy 
- Foto-fermentation - organic materials are transformed by bacteria to hydrogen. Can be combined with hydrogen fermentation.

\section{HYDROGEN FUEL CELL VEHICLE}

Hydrogen fuel cell powered vehicle is basically an electromobile, that is powered by hydrogen fuel cell that are gathered to the fuel cell stacks. One stack is designed to contain enough energy to provide necessary power for the automotive application. The energy is produced as long as fuel is available and it is similar to the combustion engine. Energy of fuel cell stack powers the electric motor that propels the vehicle. Fuel cell are not using combustion of hydrogen to produce energy but energy hidden in atoms are transforming directly to electric energy. For those purposes is also used oxygen that electrochemically reacts with hydrogen, that produces water and electric energy

\section{Hydrogen fuel cell function}

Hydrogen fuel cell contains of electrodes, that are mainly made of carbon, that is cover thin layer of platina or platina and ruthenium alloy (Fig. 3). These electrodes are placed on both sides of membrane (polymer folia), that is able to transfer ions. If the anodes are connected with conductive plates that are delivering on one side hydrogen and on the other oxygen (respectively air) it is possible to gain electric energy.

Electric energy is produced by dividing of hydrogen atoms to protons and electrons on anode. Membrane permits transfer of protons to cathode while electrons are traveling in closed circuit producing electric current. On cathode side are protons and electrons reunited again and in reaction with oxygen are forming water.

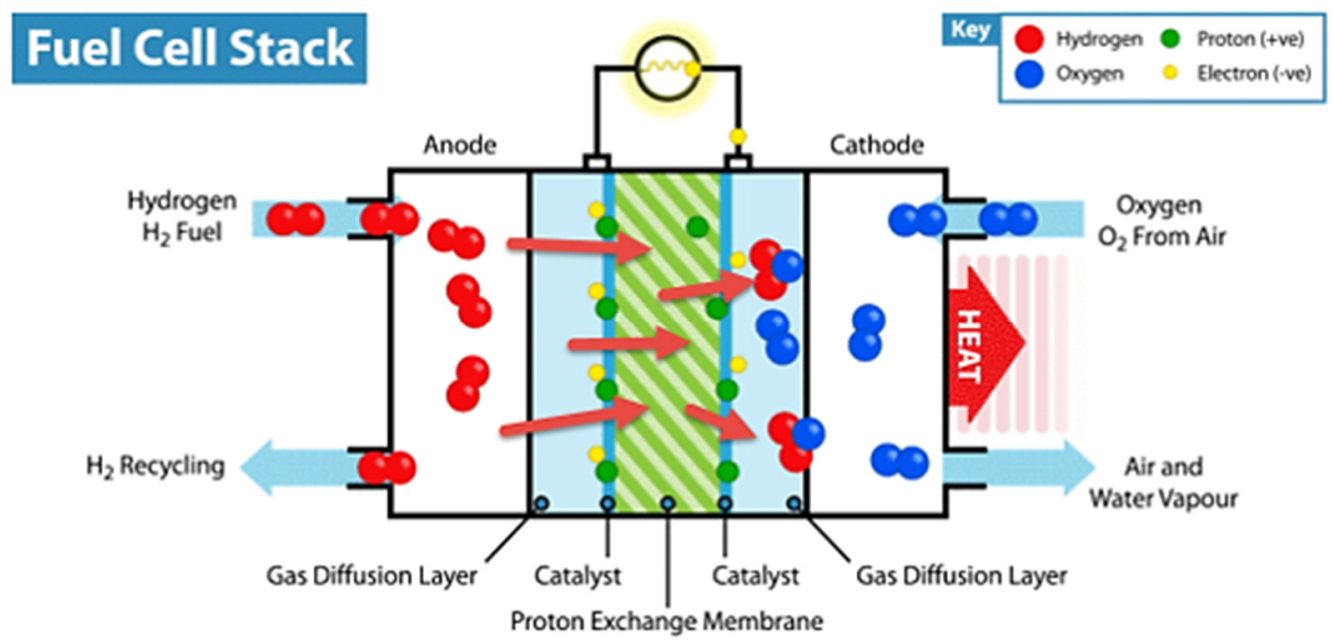

Fig. 3 Fuel Cell Stack

Theoretical efficiency varies between $80-90 \%$ due to the type of fuel, on the contrary of classic combustion engine, that is unable to gain efficiency higher than $40 \%$. Practical efficiency varies around $40-60 \%$ because of losses. After all the resultant efficiency is higher (Fig. 4). 


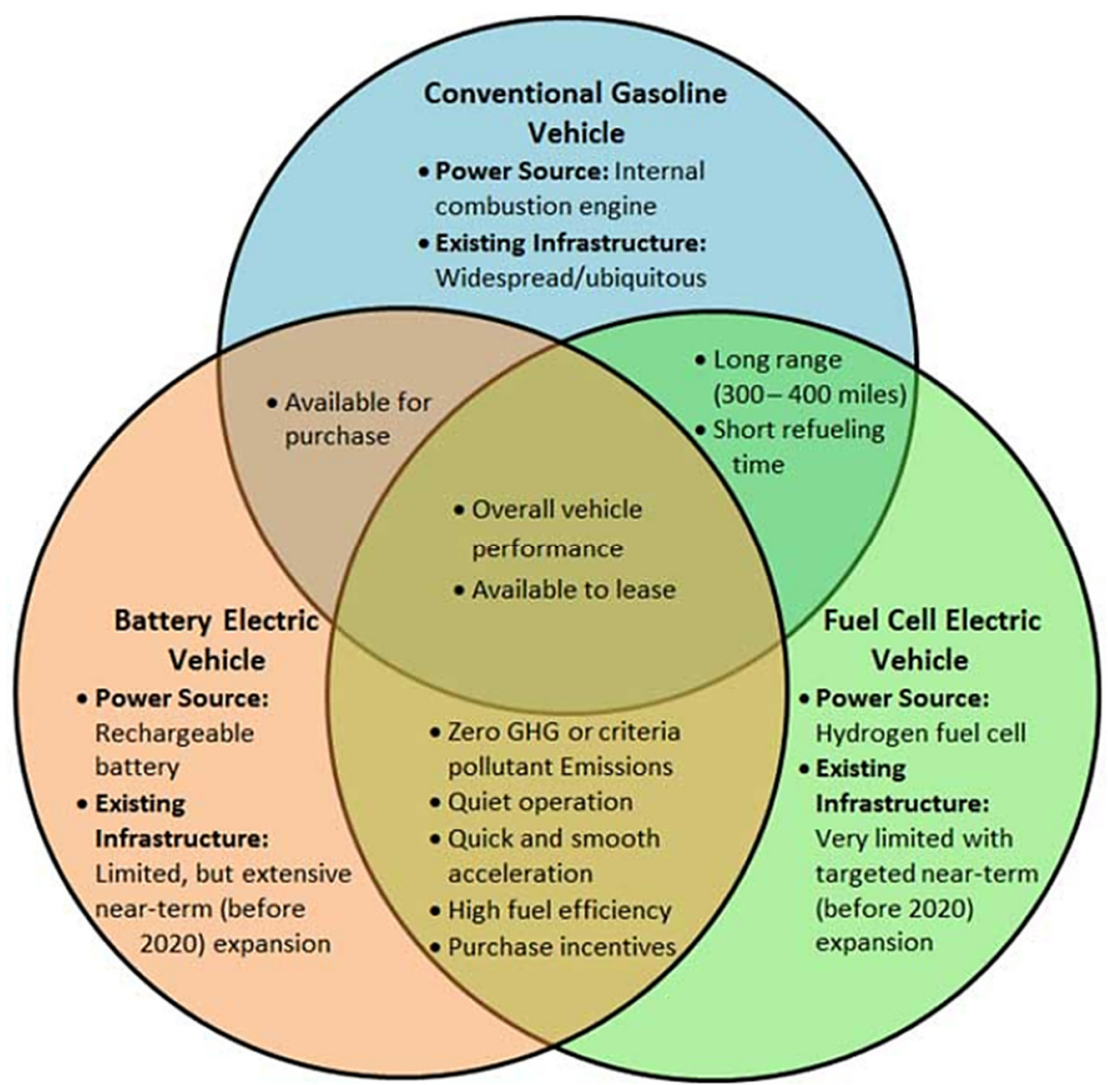

Fig. 4 Comparison of fuel type engines

\section{$\mathrm{H}_{2}$ Properties relevant for Internal Combustion Engine (ICE)}

Hydrogen as fuel is still gas and at ambient conditions are its properties significantly different from conventional liquid fuels. Table 1 shows comparison of relevant properties for hydrogen, methane (main constituent of natural gas) and iso-octane (gasoline fuel).

Table 1

Comparison of relevant properties

\begin{tabular}{|c|c|c|c|}
\hline Property & Hydrogen & Methane & Iso-octane \\
\hline Molecular weight $[\mathrm{g} / \mathrm{mol}]$ & 2.016 & 16.043 & 114.236 \\
\hline Density gaseous $\left[\mathrm{kg} / \mathrm{m}^{3}\right]$ & 0.08 & 0.65 & - \\
\hline Density liquefied $\left[\mathrm{kg} / \mathrm{m}^{3}\right]$ & 71 & $430-470$ & 692 \\
\hline Minimum ignition energy [ml] & 0.02 & 0.28 & 0.28 \\
\hline Minimum quenching distance [mm] & 0.64 & 2.03 & 3.5 \\
\hline Lower heating value $[\mathrm{MJ} / \mathrm{kg}]$ & 120 & 50 & 44.3 \\
\hline Stoichiometric air/fuel ratio & 34.2 & 17.1 & 15 \\
\hline Flammability limits in air [vol\%] & $4-75$ & $5-15$ & $1.1-6$ \\
\hline Flammability limits $(\boldsymbol{\lambda})$ & $10-0.14$ & $2-0.6$ & $1.51-0.26$ \\
\hline Flammability limits $(\varphi)$ & $0.1-7.1$ & $0.5-1.67$ & $0.66-3.85$ \\
\hline
\end{tabular}

Fig. 5 graphically compares the flammability limits of hydrogen to diesel, gasoline and methane. The key of the application of lean-burn combustion strategies with hydrogen as fuel are wide flammability limits. Another factor that makes hydrogen more than suitable for lean-burn combustion concepts is the high flame speeds even under lean conditions. 


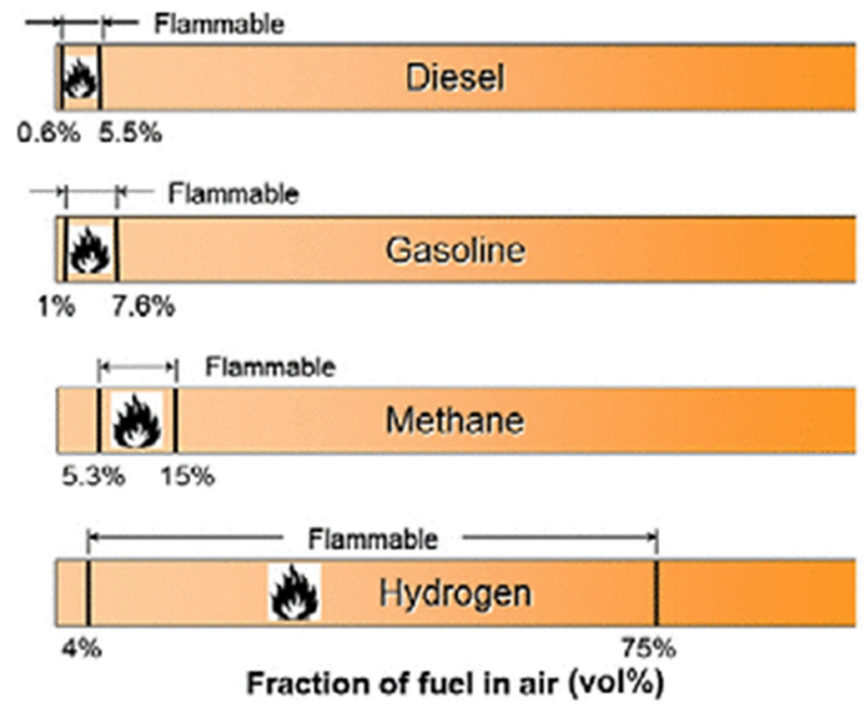

Fig. 5 Comparison of flammability limits of typical engine fuels

\section{HYDROGEN COMBUSTION ENGINE}

Because of its physical and chemical properties is hydrogen mostly used in sparkignited engines. In principal hydrogen combustion engine is just modified version of classic combustion engine. For hydrogen combustion is nowadays used modified version of conventional four-stroke petrol piston engine. This kind of engine works on cyclic principal, that is described by Otto cycle (Fig. 6):

- Intake

- Compression

- Power

- Exhaust

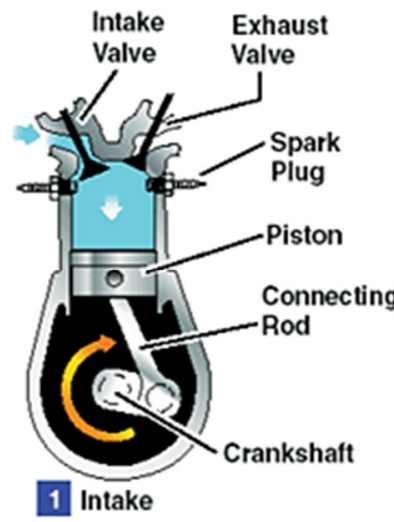

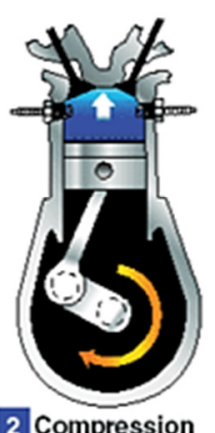

2 Compression

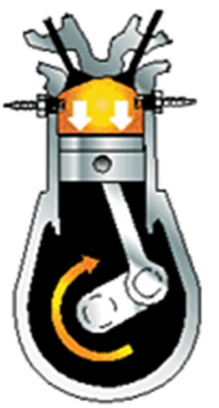

3 Power

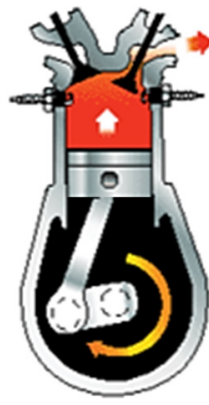

Exhaust

Fig. 6 Otto cycle

\section{Fuel mixture}

Fuel mixture is characterized by air/fuel ratio (A/F ratio). Ideal ratio comes of the chemical reaction of hydrogen combustion

$$
2 \mathrm{H}_{2}+\mathrm{O}_{2}=\mathrm{H}_{2} \mathrm{O}
$$

In the engine the combusted mixture contains air and hydrogen we have to think also about nitrogen that is a significant part of air. 
Number of moles $\mathrm{N}_{2}$ in the air:

$$
1 \mathrm{~mol} \mathrm{O}_{2} \cdot \frac{79 \% \mathrm{~N}_{2}}{21 \% \mathrm{O}_{2}}=3,762 \mathrm{~mol} \mathrm{~N}_{2}
$$

Number of moles:

$$
\mathrm{O}_{2}+N_{2}=1+3,762=4,762 \text { mol air }
$$

Mass/weight of $\mathrm{O}_{2}$ and $\mathrm{N}_{2}$

$$
\begin{gathered}
m_{\mathrm{O}_{2}}=1 \mathrm{~mol} \mathrm{O}_{2} \cdot 32 \mathrm{~g} / \mathrm{mol}=32 \mathrm{~g} \\
m_{\mathrm{N}_{2}}=3,762 \mathrm{~mol} \mathrm{~N} \cdot 28 \frac{\mathrm{g}}{\mathrm{mol}}=105,33 \mathrm{~g}
\end{gathered}
$$

Weight of air

$$
m_{\text {air }}=m_{O_{2}}+m_{N_{2}}=32+105,33=137,33 \mathrm{~g}
$$

$\mathrm{H}_{2}$ weight

$$
m_{\mathrm{H}_{2}}=2 \mathrm{~mol} \mathrm{H} \cdot 2 \frac{\mathrm{g}}{\mathrm{mol}}=4 \mathrm{~g}
$$

Stoichiometric ratio air/fuel (A/F ratio) for hydrogen and air is $A / F$ ratio based on the weight

$$
\frac{m_{\text {air }}}{m_{\text {fuel }}}=\frac{137,33}{4}=34,33: 1
$$

$\mathrm{A} / \mathrm{F}$ ratio based on volume

$$
\frac{V_{\text {air }}}{V_{\text {fuel }}}=\frac{4,762}{2}=2,4: 1
$$

Occupancy of the chamber in percent by hydrogen for stoichiometric mixture

$$
\frac{V_{\mathrm{H}_{2}}}{V_{\text {total }}}=\frac{V_{\mathrm{H}_{2}}}{\left(V_{\text {air }}+V_{\mathrm{H}_{2}}\right)}=\frac{2}{4,762+2}=0,296=29,6 \%
$$

The calculations are clearly showing that the most efficient is $34: 1$ of mass. If we would compare $A / F$ ratio of hydrogen fuel mixture to petrol fuel mixture $(A / f$ ratio $14.7: 1$ ) it is obvious that it is twice bigger. Hydrogen as gas takes $30 \%$ of the volume in the combustion space, but liquid petrol only $1-2 \%$.

\section{Problems of hydrogen combustion engines}

Most significant problem of Hydrogen is low initiative energy and wide range of flammability that causes early ignition of mixture. Combustion does not start in the ideal moment $\rightarrow$ rough and ineffective engine operation (possibility of reverse ignition and damage of whole system) (Kunovsky et al., 2013, de Valladares, 2017).

\section{Fuel systems}

To reduce or even eliminate pre-ignition of mixture is possible with use of suitable fuel system

- Central injection - mixture is produced in one place of suction tubes during intake (modified petrol engine)

- Port injection - improved central injection. Mixture is produced in tubes in more than one place, in front of the valve. Input pressure is higher than at central injection and there is lower chance of pre-ignition.

- Constant volume injection (CVI) - amount of fuel and time of injection is handled by cam.

- Electronic fuel injection (EFI) - allows to inject variable volume of fuel and change the time of it

- Direct injection - injection of fuel mixture takes place during compression. Suction 
valve is closed and fuel is injected into the engine cylinder. Direct injection engine performance is about $42 \%$ higher than central injection engine and about $20 \%$ higher than a gasoline engine.

\section{Thermodynamic efficiency}

As said above hydrogen combustion engine works on Otto cycle principal. Theoretic efficiency depends on compress ration and Poisson constant (kappa)

$$
\eta_{t h}=1-\frac{1}{\left(\frac{V_{1}}{V_{2}}\right)^{k-1}}
$$

The formula represents the fact that the higher the compression ratio or the Poisson's constant is, the greater will be the thermodynamic efficiency. In operation with leaner mixture, the hydrogen engine compression ratio is greater than ratio of a petrol engine. In today's hydrogen-fueled cars is efficiency around $42 \%$, which is about $10 \%$ higher than gasoline engines (de Valladares, 2017).

\section{DANGER OF HYDROGEN STORAGE}

In future is crucial for hydrogen technologies to secure its storage. Hydrogen has the lowest density and boiling point of all fuels, that causes several troubles in storage. In general, every fuel is dangerous. High density of energy, combustibility and explosiveness are properties similar to every fuel. Storage of fuel inside the vehicle represents danger. Hydrogen is no exception, but its behavior in comparison with other kinds of fuels is in many ways different (Gandia et al., 2013).

\section{Hydrogen security risks}

- Fast expansion can lead to self-combustion

- Combined with air is hydrogen flammable and explosive mixture

- Really low combustion energy can cause together with electrostatic charge $(0,02$ J) combustion

- Low viscosity and small dimensions of hydrogen molecules are increasing claims for gaskets of fuel tanks

- Hydrogen leak is undistinguishable

- Hydrogen is spreading fast (low density) $\rightarrow$ quick decrease of concentration under the combustion level

- Hydrogen flame is almost invisible on the daylight

Although the parameters shown above are less favorable to other fuels, practical tests have shown less destructive effects of hydrogen tank flare to the vehicle and with it connected risk to the passengers. If the tank is damaged, hydrogen will rise due to its low density and possible fire will occur outside of the vehicle. The safety is increasing also smaller amount of stored fuel. Furthermore, it is possible to increase the safety by suitable positioning of the tank (Gandia et al., 2013).

\section{Hydrogen storage}

In comparison with conventional fuels is very hard to storage hydrogen. With same weight and volume of the tank is energy of stored fuel several times lower. For hydrogen use in the transportation is technologically easier to use compressed 
hydrogen. Technologies of hydrogen storage is possible to divide into two groups to conventional and alternative (Hydrogen and fuel cells).

\section{Conventional storage methods}

Storage of gaseous hydrogen - system for hydrogen storage in high pressure tanks is simple and well known method with plenty of analysis and legislative that secures its safety. It is most used method in the transportation and industry.

Storage of liquid hydrogen - second in industry widely used method is storage of liquid hydrogen. This method is more complicated, expensive and with higher demands on energy. Hydrogen has to be cooled under the boiling temperature under pressure. Whole process of cooling and compression leads to almost $30 \%$ loss of energy preserved in hydrogen. Cryogenic storage of hydrogen (Fig. 7) allows rapid increase of energy density.

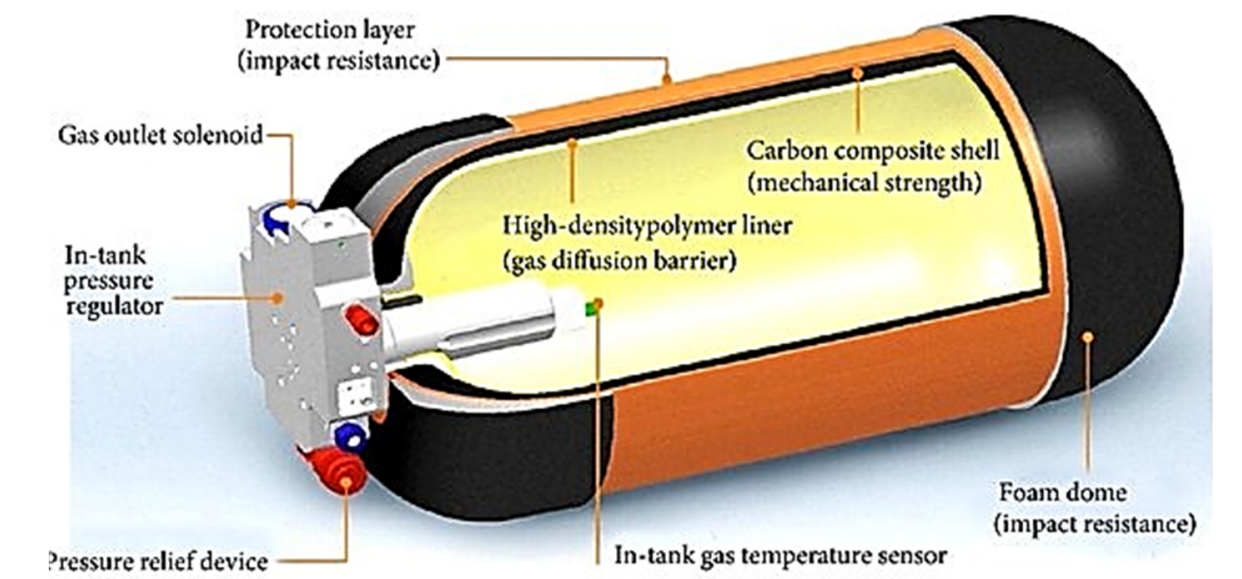

Fig. 7 Schematic diagram of a 4 type vessel and its components for gaseous hydrogen storage

Liquid hydrogen with temperature $-253^{\circ} \mathrm{C}$ and pressure $101.3 \mathrm{kPa}$ takes 848 time less space than gaseous hydrogen. Energy of one liter of liquid hydrogen is around 8.5 MJ. That is roughly four times less in comparison with petrol.

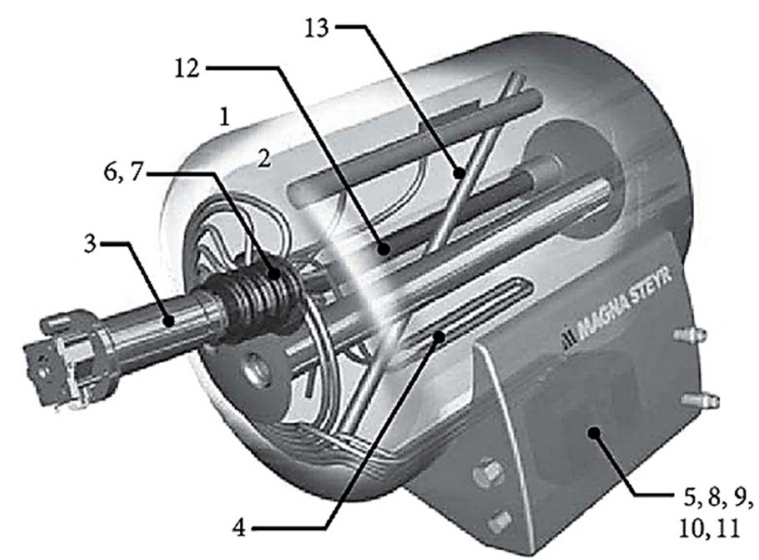

Fig. 8 Schematic diagram of a liquid hydrogen tank and its components

(1) Outer tank, (2) Inner tank, (3) Coupling (Johnston-Cox), (4) Heater,

(5) Heat exchanger, (6) Cryogenic filling valve, (7) Cryogenic return valve,

(8) Pressure regulation valve, (9) Shut-off valve, (10) Boil-off valve,

(11) Safety relief valve, (12) Support post, (13) Liquid level sensor 


\section{Alternative storage methods}

We can divide alternative methods to several categories

- Systems on the hydride bases

- Metal - hydrides

- Complex hydrides

- Hydrogen absorbed in nanostructures

- Hydrogen chemically bounded in compounds

- Hydrogen in glass micro-marbles

Systems of hydrogen storage in hydride works on the principle of hydrogen absorption into metallic material. Absorption is exothermic reaction and produces heat. Metal hydrides are considered as safe method of storage for use in transportation (Váchová, 2006).

\section{HYDROGEN APPLICATION}

Hydrogen as fuel is suitable for use in different fields of industry, but special place for it is in the transportation.

- The light duty passenger vehicle - these machines are already on the roads for some time. Speaking about performance of FCEV (fuel cell electro vehicle) is comparable to the conventional vehicle with a range of 250-350 miles per tank.

- Small commercial and logistics vehicles, Heavy duty trucks - offer opportunities for hydrogen. These vehicles are differentiated by weight and payload capacity. Pollution is driving a shift to alternative fuel powertrains, including fuel cell powertrains, in various classes of commercial/industrial trucks

- Trains and light rail - in 2002 was first demonstrated hydrogen-powered mining locomotive and in 2006, the east Japan Railway Company developer the world's first derail car. Commercial use of fuel cell powered trams and light rail is still increasing.

- Power and Heat - Hydrogen can expand supply in the power sector via use of electricity from renewable sources to electrolyze water for storage. Furthermore, hydrogen can be used to provide heat. Heating are critical application worldwide. Power and heat are interrelated. Fuel cells are a modular, scalable technology that can be used for CHP (combined heat and power) and produce the highest proportion of electricity of any CHP technology

- Industrial applications - Use of hydrogen could displace the oil used in chemicals and petrochemicals and the coal used in iron and steel. Hydrogen may be used as reductant in steel production (de Valladares, 2017).

\section{CONCLUSION}

The rapidly changing environment gives enterprises increasingly difficult requirements (Grabowska 2018). In the time of diminution of natural resources together with fossil fuels and the demands on sustainability and development of transport and industry, we need to look for possible and mainly renewable sources of energy. Transport is a part of a business model but the model with trust. Different models between participants in supply chains help to solve different problems. Models of building trust in the supply chain are developed in particular sectors (branches) of industry, eg in metallurgical sector. The subject hydrogen fuel in transportation can 
be included in the business model particular participates of supply chain based on trust (Gajdzik, Grzybowska 2012). An additional references in the building of business models is the strategy, taking into account the environmental aspects, which is includes in the topic (subject) of the paper (Gajdzik 2009). The main advantage of using hydrogen as a fuel are, with the right technology and application, emissions that can be minimized to zero. The problem with mass use of hydrogen as fuel for transport and industry is the almost non-existing infrastructure reliable for the end customer, and the fact that the major hydrogen production is done by method called steam reforming, where hydrogen is obtained from fossil fuels. If we want to consider hydrogen as an environmentally friendly way how to propel machines, it is necessary to develop other not so widespread ways of obtaining hydrogen such as biotechnological processes. In terms of security, the article shows that the general fear of hydrogen is unreasonable as long as we comply with all the security. Furthermore, the article clearly shows that today is common to see hydrogen technologies both on the road and in the industry and that their mass expansion is only a matter of time.

\section{ACKNOWLEDGEMENTS}

This article has been written in connection with the project The research and innovation of modern technologies in manufacturing practice, reg. no. SP2019/2 supported by Specific Research program financed by the Ministry of Education, Youth and Sports.

\section{REFEENCES}

Bołoz, Ł., Midor, K. (2018). Process innovations in mining industry and effects of their implementation presented on example of longwall milling heads. Acta Montanistica Slovaca, 3.

Energetika v ČR, Čísla a statistiky. (2019). [online] Skupina ČEZ. Energy in the Czech Republic, Numbers and Statistics. Available at: https://www.cez.cz [Accessed 14 May 2019].

Gandia, L., Arzamedi, M., Dieguez, G., Pedro M. Renewable Hydrogen Technologies Production, Purification, Storage, Applications and Safety - 16.1.1 H2-Internal Combustion Engine vs. Fuel Cell. Elsevier.

Gajdzik, B. (2009). Environmental aspects, strategies and waste logistic system based on the example of metallurgical company, Metalurgija 48(1) pp. 63-67.

Gajdzik, B., Grzybowska, K (2012). Example models of building trust in supply chains of metallurgical enterprises. Metalurgija, 51(4), pp. 563-566

Grabowska, S. (2018). Improvement of the heat treatment process in the Industry 4.0 context. In: METAL 2018. 27th International Conference on Metallurgy and Materials, May 23rd - 25th, 2018, Brno, Czech Republic. Conference proceedings. Ostrava: Tanger, 2018, (CD-ROM) pp. 1985-1990.

Hydrogen and fuel (2010c). Cells: fundamentals, technologies and applications. Weinheim: Wiley-VCH, ISBN 978-3-527-32711-9.

Matisková, D., Kotus, M., Balara, M. (2016). Automatic thermal control system with temperature difference or derivation feedback. TEM Journal - Technology education management informatics, 5(1), pp.60-66.

Mlčoch, J., Dittrich, R., Kaufman, T., Fries, J. (2015). Mobile crane for construction of wind power plants. SGEM Albena, Bulgaria. Sofia: STEF92 Technology Ltd., 2015, 329-336 pp. DOI: 10.5593/SGEM2015/B41/S17.043.

Sankir, M., Demirci. N. Hydrogen Production Technologies. John Wiley \& Sons. Available at: https://app.knovel.com/hotlink/toc/id:kpHPT00001/hydrogen-product-iontechnologies/hydrogen-production-technologies. 
Váchová, M. (2016). Vodík - alternativní zdroj energie. Hydrogen - an alternative source of energy. Spektrum. Ostrava: Sdružení požárního a bezpečnostního inženýrství, 6(1), 4142.

Valladares, M.-R. (2017). Global Trends and Outlook for Hydrogen, IEA Hydrogen Technology Collaboration Program (TCP), pp. 20.

\begin{abstract}
In the time, when the whole world is increasingly engaged in environmental protection, it is necessary to come up with a fuel alternative for transportation, which means generally abandon the use of non-renewable resources (petrol, oil and fossil fuel in general), as they are one of the many factors influencing the emergence of greenhouse gases and the associated global warming. In today's Europe, the pressure is put mainly on automotive companies, to search for sources other than conventional fuels. At present, there is a big boom in the area of electric cars powered from the power network - the vast majority of electric energy, however, is produced in fossil fuel power plants. The second option of possible development in this area is the use of hydrogen as an alternative fuel. This technology, whether it be direct combustion as in diesel or eventually in petrol engines, or energy production in a hydrogen fuel cell, is certainly the way suitable for further development. With hydrogen as a fuel, it is possible to reduce pollutants almost to zero. The article presents a comparison of electricity generated using renewable and non-renewable sources and focuses on a closer understanding of the myth of the dangers connected with using hydrogen as fuel. Furthermore, compares conventional fuels to re-newable hydrogen technologies and focuses on the hydrogen combustion engines together with hydrogen storage and application in transportation.
\end{abstract}

Keywords: Hydrogen, hydrogen fuel cell, hydrogen combustion, renewable energy 